JPE (Jurnal Pendidikan Edutama) Vol. 6 No. 1 Januari 2019

P-ISSN : 2339-2258 (Print) E-ISSN: 2548-821X (Online)

http://ejurnal.ikippgribojonegoro.ac.id/index.php/JPE

\title{
AN ANALYSIS OF DIRECTED DIALOGUE JOURNAL TO IMPROVE WRITING SKILL ON NEWS ITEMS TEXTS FOR INDONESIAN EFL UNIVERSITY STUDENTS
}

\author{
Mohammad Fatoni ${ }^{1)}$ \\ ${ }^{1}$ Faculty of Teacher Training and Education, Universitas Nahdlatul Ulama Sunan Giri \\ email: mohammadfatoni@unugiri.ac.id
}

\begin{abstract}
This study aims to analyze the directed dialogue journal on news items texts for Indonesian EFL University Students in term of (1) the students' problems in using directed dialogue journal (2) how the students' writing after using directed dialogue journal. This research used classroom action research method. Analysis of the problems in using directed dialogue journal on news item texts was analyzed descriptively and the university students' news items writings were analyzed in all components of writing. Results of the analysis reveals that the problems in using directed dialogue journals were lack of time and idea to response the comments. However, the lecturer were able to overcome those problems by planning what he did in the lesson plan efficiently and training how to response the comments in the written conversation to improve their writing. In successions overall, there was significant improvement on the students class mastery of final draft from the first to third cycles. They were $38.5 \%, 65 \%, 92 \%$. Content was the writing component that improves significantly in this research. It means that directed dialogue journal on news items texts was able to improve the students writing skill when the problems were identified and solved.
\end{abstract}

Keywords: directed dialogue journal, news items texts, writing components

\begin{abstract}
Abstrak: Penelitian ini bertujuan untuk menganalisis dialog jurnal terarah pada penulisan teks berita yang ditujukan untuk mahasiswa Indonesia yang menggunakan bahasa inggris sebagai bahasa asing dalam hal (1) permasalahan yang mahasiswa hadapi dalam menggunakan dialog jurnal terarah dan (2) bagaimana tulisan mahasiswa setelah menggunakan dialog jurnal terarah. Penelitian ini menggunakan metode penelitian tindakan kelas. Masalah dalam menerapkan dialog jurnal terarah pada teks berita berita dianalisis secara deskriptif dan semua komponen teks tulis berita mahasiswa dianalisis. Hasil analisis mengungkapkan bahwa masalah dalam melaksanakan dialog jurnal terarah adalah kurangnya waktu dan ide untuk merespon komentar yang diberikan. Namun, dosen mampu mengatasi masalah tersebut dengan merencanakan apa yang dia lakukan dalam rencana pengajaran secara efisien dan melatih bagaimana merespon komentar dalam percakapan tertulis untuk meningkatkan tulisan mereka. Secara berturut-turut, ada peningkatan yang signifikan pada penguasaan kemampuan menulis pada draf akhir dari siklus pertama hingga ketiga sebesar 38,5\%, 65\%, 92\%. Isi merupakan komponen tulisan yang meningkat secara signifikan dalam penelitian ini. Hal ini menunjukkan pengunaan dialog jurnal terarah pada materi teks berita dapat meningkatkan keterampilan menulis mahasiswa ketika permasalahannya diidentifikasi dan dipecahkan.
\end{abstract}

Kata kunci: dialog jurnal terarah, teks berita, komponen tulisan. 


\section{INTRODUCTION}

Writing for students not only in school but also in university level becomes one of the skill which demanded to master. The final of teaching writing, the lecturer assigns them to write certain texts to accomplish the final project like descriptive texts, news items texts, narrative texts, scientific writings, and thesis. Because of the important of writing, the university students should learn and able to produce writing texts well. They should understand the process of writing and the structure of certain texts to make appropriate writing texts.

The university students' writing skill still has some problems. Their understanding about generics structure and language features in certain texts need to be refreshed to make their writing easily understood by the readers. Seyabi and Tuzlukova (2014) claims the problems of writing into five main types include insufficient ideas about the topics that they want to write, the appropriate vocabulary to deliver their meaning, what they should write in the beginning of their essay, the correct English sentences and how to make their paragraph coherent. In the writing process, the discussion between lecturer and university students are conducted to make their writing better. They usually discuss about the quality of their draft either oral or written in the class, it can also does in electronic way such as e-mail, blog, facebook, etc. They also realize that to impove the quality of writing can not be done in once consultation to the lecturer. They need continuous comment to make their drafts better and better.

In fact, the quality of the university students' writings need improvement. Their ideas are not organized well, still many grammatical errors and the readers are confused to grab the idea clearly. To enhance their writing, they need lecturer's comments to fix their writing in order to be easy to understand. Their writing need to be improved in term of idea, generic structure and language features. Muncie (2000, p. 52) claims feedback from lecturer is able to give contribution to the university students' writings quality. The university students are able to correct their error by observing the feedback given by their lecturer. According to Ellis (2009, p.3) ensuring linguistics accuracy is one of the function of feedback. The functions of feedback in the students' writing are to make the students' writing development and show the strength and weaknesses of our writing. So, dialogue journal is appropriately used to improve the university students writing skill in university level. Dialogue journals are between the university students and lecturer do written conversation and use the students' writing as a media to discuss rather than an evaluator who corrects the students' writings (Peyton, 2000). Meanwhile, directed dialogue journal, the university students are assigned a certain topic to explore in their writing. In this research, the topic used is news items that is chosen by the lecturer. The university students are asked to make news items about hot news in our country. Although dialogue journals typically as medium for meaningful communication rather than a means to focus on form, Ellis (2008) suggests adult English learner could have many beneficial in this writing if focus on form was thoughtfully incorporated. So, it is better to use dialogue journal not only in term of content but also all components of writings.

The researcher tries to implement this technique in Universitas Nahdlatul Ulama Sunan Giri, especially $1^{\text {st }}$ semester writing class. The students of this 
university are chosen because the researcher believes the university students' news items essay still have the problems and also the result of the interview with the university students indicate they have problems in writing class. To confirm about the problems, the researcher conducts preliminary study in this class. The result is only 4 students (10\%) who get score 70 or higher. It means that most of them still can not write news items well. The result of it can be the indicator to determine the class whether it has the problem or not. The researcher expects that the result of conducting this research will lead the students to write better. The criteria of success in this research at least $75 \%$ university students get score 70 or higher.

This research intended to answer the reseach questions (1) what are the problems faced by the university students to apply directed dialogue journal? (2) how are the university students' news items texts after using directed dialogue journal?

\section{METHOD}

The goal of this research is to analyze of directed dialogue journal on writing news items for indonesian EFL university students in term of the students' problems in using directed dialogue journal and the students' writing after using directed dialogue journal. This study was a classroom action research. It was an approach to improve the quality of education through change, the lecturer should be critical of what he did in the class and did reflection to change it when the result was not on the target standards. Meanwhile, Mills (2011) argued that action research was systematics procedures which were implemented by lecturer to improve the quality of education in term of the teacher teaching strategy, what the students did in the teaching learning process and the situation in teaching learning process. Mc Niff (2010) stated action research model showed the self-reflective spiral of planning, acting, observing, reflecting, replanning as the foundation for a problemsolving. In this research, the researcher took part in a class as a lecturer as well as researcher to take the data.

The subject of the study was observed by the researcher over a period of time during treatments. The resercher used action-reflection spiral model as proposed by McNiff (2010). Explanation instead of the prescription one was used in McNiff's. Explanation was important as long as the research concern with the educational field. McNiff (2010, p. 34) quoted Chomsky's statement as follows, "...Those of observation, description, and explanation were at least three such levels in any enquiry method". So, The researcher did observation to identify the situation, described the situation in the class and explained what he understood about the situation. When the situation was not like he expected, he prepared the best way in next teaching learning process.

The detailed model was illustrated as follows:

Picture 1. Cycles of Classroom Action Research

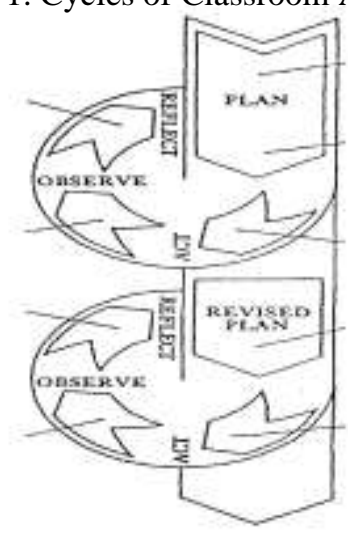


The subject of this study was $1^{\text {st }}$ semester students of Nahdlatul Ulama Sunan Giri University because it had students from heterogeneous background, level of English competence and they got the news items text in their writing class. This class consisted of 40 students, 28 girls and 12 boys. They consisted of above average, average and below average students in term of English competence.

The data comprised the observation checklist result, interview and the score of the students' competence in their writing proficiency from several times of assessment during the observation. These data were the answers whether the directed dialogue journal gave the contribution to their writing ability or not. The data would be presented in the descriptive and numerical form. The descriptive one was used to explain the result of the observation checklist and interview. Meanwhile, the numerical form was the score of the students' writing proficiency measured by using modified ESL composition profile.

The data were collected into three cycles during the research. In each cycles, the data were collected through four stages. They were planning stage, acting stage, observation stages and reflection.

\section{RESULT AND DISCUSSION}

The problems faced by the students in using directed dialogue journal

Directed dialogue journal usually did in the writing class to help the students writing. However, there were some problems in the class when they did it. Based on the observation checklist result in the writing class and interview with the students, they had difficulty in directed dialogue journal in term of lack of ideas and how to response. It was not always easy to write the idea and reply the comment in written conversation. They sometimes had difficulty in delivering their ideas into meaningful sentences. They were confused what they wanted to talk because they didn't have any idea and also how to give response towards the lecturer suggestion in their writings. This was in line with Lee (2004) argued that the university students were not easy to come up with idea when they did written conversation in dialogue journal. However, the lecturer always stimulated and guided the students how to write the idea, reply the comment in written conversation and response towards the lecturer comments. These techniques worked and made the students were able to make their writings better.

In addition, when the lecturer gave comment to their writings, it was not always easy to revise their writings. They are sometimes confused how to make their writing better based on the comment given in the written conversation. In the interview, the university students also argued they did not know the parts that they should improve in their writing. However, the lecturer guided them what they should do with their comments by conducting the training.

The second problems was about lack of time. They needed a lot of time when using directed dialogue journal. They should do written conversation between teacher and students in much time. They argued that they sometimes did clarification to understand what the teacher want to do for their writing. They were aware that to do clarification was important however the time was problem when they did the directed dialogue journal for their writings. However, they should do it to negotiate the meaning.

They felt the time that is used in dialogue journal was so fast. They spent much time in doing dialogue journal. This was in line with Garmon (2001) stated the 
reflection and clarify the message in dialogue journal was important to do however the problem is about the time. Orem (2001) claimed written conversation between students-lecturer consequently made heavy work-load exchange for lecturer and time consuming. So, the lecturer did planning in order that the time that was used effectively. He made the planning in the lesson plan what he did to manage the time well. He also arranged the activities to make the teaching learning process ran well.

The lecturer were able to overcome those problems by planning what he did in the lesson plan efficiently. He managed the time efficiently by directly teaching them the structure of the text and doing written conversation to make their writing better. $\mathrm{He}$ also used familiar words and simple sentences to make them understand the comment, what they should do and make their writings better.

\section{The university students' news items texts after using directed dialogue journal}

In analyzing the contribution of directed dialogue journal toward the students' news items texts, the improvement students' score in each cycle were categorized into the table. He listed the average, the lowest, the highest score and the class mastery of writing news items text either rough drafts or final drafts in each cycle. The rough drafts meant the drafts that the university students wrote for the first time before using directed dialogue journal. While, Final drafts meant the drafts that university students revised and edited based on the conversation, comments and suggestion from the lecturers. The researchers are able to observe this table below to analyze the students improvement score in news items texts by using directed

dialogue journal. The table could be seen as follows

Tabel 1 The Students' Score and Percentage of the Class Mastery

\begin{tabular}{cllllll}
\hline & \multicolumn{2}{c}{ Quiz 1 } & \multicolumn{2}{c}{ Quiz 2 } & \multicolumn{2}{c}{ Quiz 3 } \\
\hline & R1 & R2 & R1 & R2 & R1 & R2 \\
\hline Average & 57 & 69 & 63 & 71 & 66 & 79 \\
\hline Score Min & 38 & 40 & 58 & 60 & 50 & 63 \\
\hline Score Max & 75 & 88 & 78 & 88 & 80 & 90 \\
\hline Class & $15 \%$ & & $25 \%$ & & $27.5 \%$ & \\
Mastery & $47.5 \%$ & $65 \%$ & & $92.5 \%$ & \\
\hline
\end{tabular}

Note: R1= Rough drafts' Score

R2= Final drafts' Score

Based on the table above, the first cycle of rough drafts' average score was 57 . The gap score between highest score (75) and the lowest score (38) was too high. It meant that the writing skill between above and below average were still far difference. above average students, only few students, were able to reach max score 75 meant they were able to write news items well. Based on the score that the students got, one of the problem was the students were not able to write news items texts well. This could be seen from the percentage of the class mastery $(15 \%)$. There were only 6 of 40 students who could get the score 7 or higher. Meanwhile, the average score of final drafts at first cycle was 69. The gap score between highest score (88) and lowest 
score (40) was 48. The percentage of the class mastery improved to be $(47.5 \%)$. There were only 19 of 40 students who reached the standarized score 7 or higher. The improvement score was caused by the suggestions and comments in their written conversation in dialogue journal for their writings. However, only a few students could understand what the teacher wanted in written dialogue to revise and edit their writing based on the suggestion because they were still confused how to revise and edit their draft based on the written conversation in directed dialogue journal. There was a positive result in this case, although, their score of final draft still could not reach the indicator of the achievement (75\%).

The better planning was made by the lecturer to make the students understand how to response the written conversation in the directed dialogue journal. To make them understand well about the news items text, he also taught them the generic structure and the language feature of news items text. The lecturer also planned what he did well in the lesson plan to managed the time efficiently. In cycle 2 , the average score of rough drafts was 63 . The gap score between highest score (78) and lowest score (58) was still high. It meant that there were still gap between the above and below average students in news items writing skill although it was not higher than it was in first cycle. The number of students who could write new items in rough draft improved. This could be seen from the percentage of the class mastery (25\%). There were 10 of 40 students who got score 7 or higher. As a result the teacher made the change of teaching them how to write news items texts well by identifying the use of generic structure and language features in the previous cycle. Their average score of final draft was 71. The gap score between highest score (88) and lowest score (60) was 28. It meant that there was high difference between the smartest and lowest learner in news items writing skill. It meant the university students still have different ability to response the written conversation in dialogue journal. The class mastery score was surprising. There were 26 of 40 students who got score 7 or higher $(65 \%)$. This was a good result and showed that the students could response the comment in written conversation to make their drafts well. Although, they still did not reach the indicator of success $(75 \%)$.

In cycle 3, the students' average score of their rough drafts was 66 . The gap of the highest (80) and lowest score (50) was 30 . The class mastery of the students' rough drafts was $27.5 \%$. There were 11 of 40 students who got score 7 or higher. The class mastery of the students' rough drafts improved. The cause of it was they had already known the way to write news items texts appropriately. After the teacher had guided step by step how to response the written conversation in directed dialogue journal.

Thus, the teacher improved the technique in the teaching and learning process in order to get the better result. In cycle 3 , He emphasized how to response written conversation in the directed dialogue journal to improve their writing appropriately. He also did training and showed some examples how to response written conversation, comments and suggestion in written conversation. The lecturer also planned what he did well in the lesson plan to managed the time efficiently. It could be seen from the average score of final draft, it was 79 . The range score from highest score (90) and lowest score (63). The class mastery was surprising. There were 37 students who got score 7 or higher $(92.5 \%)$. In this cycle, they could reach the indicator of the success. Based on the resercher's analysis, 
the students university content developed significantly from cycle 1 to 3 . They were able to develop their content well because they were able to response the comment and suggestion on the written conversation in directed dialogue journal. They also developed the news clearly and made the readers were able to grab the message clearly.

The progress of first to the third university students' final drafts, they had the mean score 69, 71, 79. In successions overall, there was significant improvement on the students class mastery of final draft from the first to the third cycle. They were $47.5 \%, 65 \%, 92.5 \%$. This result was in line with the research (Nassaji \& Cumming, 2000; Werderich, 2002; Miller, 2007) claimed that the use of dialogue journals were able to improve writing quality and students' confidence to discuss their writings. On the other hand, This result also contrast to Duppenthaler (2004) claimed journal writing did not have significant effect on the students' writing in the writing class. In the researcher's analysis, Duppenthaler just let the class did the directed dialogue journal without any training and seminar how to do appropriate directed dialogue journal.

Picture 2. Diagram of Students' Rough and Final Drafts

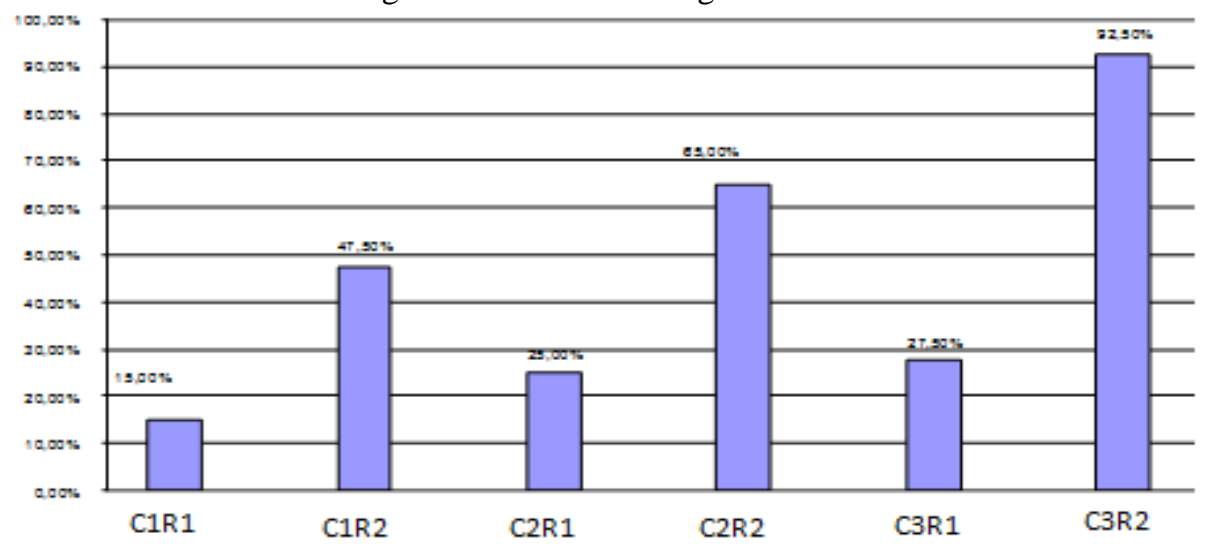

The Students' Rough and Final Drafts

Note:

\section{C1R1 = Cycle 1 Rough Drafts' Score C1R2= Cycle 1 Final Drafts' Score C2R1 = Cycle 2 Rough Drafts' Score $\mathrm{C} 2 \mathrm{R} 2=$ Cycle 2 Final Drafts' Score}

By considering the total average score and class mastery in each cycle, the last one revealed the expecting result. This progress could be used to answer the question on how the students news items writings score by using directed dialogue journal. The improvement score could be seen in the following diagram.
C3R1 = Cycle 3 Rough Drafts' Score $\mathrm{C} 3 \mathrm{R} 2=$ Cycle 3 Final Drafts' Score

Based on the diagram above, it could be concluded that the directed dialogue journal was successfully applied to improve the students' news items text skill for $1^{\text {st }}$ semester students of university.

\section{CONCLUSION}

Directed dialogue journal can be used in our writing class to improve the 
students' writing. However, there are two problems when we used it. They are lack of idea and time. The lecturer can overcome.

Those problems by planning what he did in the lesson plan efficiently and training how to response the comments in the written conversation to improve their writing. When he can overcome the problems, their writings will improve significantly.

There is improvement on the students' writing ability by using this technique. The students rough draft and final draft show the significant score after implementing this method. The development of the students' content were able to improve significantly in this

\section{REFERENCES}

Duppenthaler, P. (2004). Journal writing and the question of transfer of skills to other types of writing. JALT Journal, 26, 171-188

Ellis, R. (2008). Principles of instructed second language acquisition. CAL Digest, Washington, D.C: Center for Applied Linguistics.Retrieved from http://www.cal.org/resources/digest/d igest pdfs/Instructed2ndLangFinalW eb.pdf.

Ellis, R. (2009). Corrective Feedback and Teacher Development. L2 Journal, 1(1), 3-18

Garmon, M. A. (2001). The benefits of dialogue journals: What prospective teachers say. Teacher Education Quarterly, 28(4), 37-50.

Lee, I. (2004). Using Dialogue Journals as a Multi-Purpose Tool for Preservice Teacher Preparation:How Effective Is It?.Teacher Education Quarterly, Summer 2004, 73-97

Liao, Ming-Tzu, \& Wong, Chia-Tzu. (2010). Effets of Dialogue Journals on L2 Students' Writing Fluency, research. This makes the reader understood the message clearly.

The writer suggests the other researchers to conduct the research in other aspects of directed dialogue journal such as the different improvement between nondirected dialogue journal and directed dialogue journal, the characteristics of the university students written conversation and response towards the lecturer's written conversation. This research can be taken as the previous study and supporting data to do further research.

Reflections, Anxiety, and Motivation. Reflections on English Language Teaching, 9(2), 139-170

McNiff, J. (2010). Action Research: Principles and Practice. New York: Champon and Hall, Inc.

Miller, J. (2007). Inscribing identity: insights for teaching from ESL students' journals. TESLE Canada Journal, 25(1)

Mills, G. E. (2011). Action research: A guide for the teacher researcher (with MyEducationLab). (4th ed.). Upper Saddle River, NJ: Pearson/Allyn \& Bacon.

Muncie, J. (2000). Using Written Teacher Feedback in EFL Composition Classes. ELT Journal, 54(1), 47-53

Nassaji, H. \& Cumming, A. (2000). What's in a ZPD? A case study of a young ESL student... Language Teaching Research, 4(2), 95-121.

Orem, R. A. (2001). Journal Writing in Adult ESL: Improving Practice Through Reflective Writing. New 
Directions for Adult and Continuing Education, 90(1), 69-77

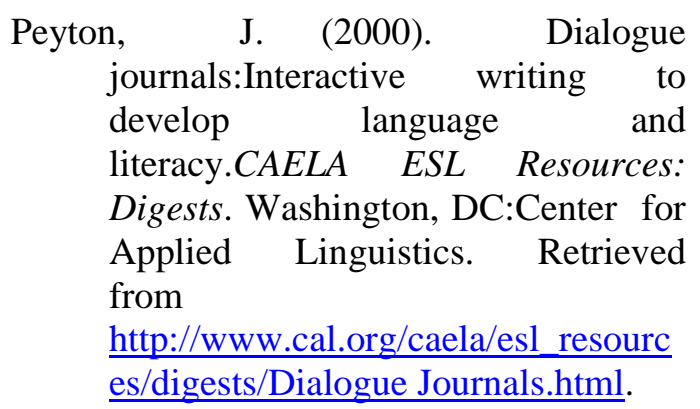

Seyabi, F. A. \& Tuzlukova, V. (2014). Writing Problems and Strategies: An Investigative Study in the Omani School and University Context. Asian Journal of Social Science \& Humanities, 3(4), 37-48

Werderich, D. (2002). Individualized responses: Using journal letters as a vehicle for differentiated reading instruction. Journal of Adolescent \& Adult Literacy, 45(8), 746-54. 
10 JURNAL PENDIDIKAN EDUTAMA, Vol.6, No.1 Januari 2019 